It is suggested from the following experiments that two different mechanisms (apart from autodecom. position) may operate in blood under certain conditions.

Examination of the effect of $p H$ showed that decarboxylation occurred for the full range tested, namely, $p H$ 8 $4-3 \cdot 5$. No experiments were carried out at $p \mathrm{H}$ values lower than $3 \cdot 5$. It was seen that, at the latter $p H$, very great activity is still obtained in both hæmolysates and plasma. Actually, that of the hæmolysate is definitely greater at $p \mathrm{H} 3.5$ than at any other $p H$ tested, in spite of the very large correction due to the autodecomposition, whereas plasma seemed to show optimal activity between pH 4 and 5. Since it seems almost certain that an enzyme of this type would not have a $p H$ optimum at 3.5 (or even below this value), the existence of a second, non-enzymatic mechanism is suggested under conditions of very low $p H$. This suggestion is very strikingly supported by the following experiments in which the system was first boiled at a certain $p \mathbf{H}$, and the decarboxylative activity afterwards determined at the same $p H$ (after readjustment, if necessary).

Boiling acetone powder extracts or diluted hæmolysates at $p H \mathbf{H} \cdot 5$ for less than $1 \mathrm{~min}$. causes almost complete cessation of the ability afterwards to decarboxylate the substrate. However, boiling the same hæmolysate or plasma samples at $p \mathbf{H} 3 \cdot 5-4 \cdot 0$ not only failed to cause such reductions in activity, but usually, especially in the case of hæmolysates, a more rapid decarboxylation for the boiled sample was observed when compared with an unboiled control.

To account for these consistent, unusual results, the following hypothesis is suggested. At physio. logical $p \mathrm{H}$, decomposition of oxalacetate is brought about by an enzymatic, heat-labile process, in which manganous ions and, to a less extent, magnesium ions, but not thiamine, are involved. The system may thus be similar to the enzymes in pigeon liver described by Evans et al. ${ }^{2}$ and in bacteria by Krampitz and Werkman ${ }^{3}$. In more strongly acid solutions, however, a heat-stable decarboxylation appears which is due to the liberation of some substance previously not present in a free state. This liberation is definitely accelerated by boiling in acid solution, so that boiled samples show a more rapid evolution of carbon dioxide than the corresponding unboiled controls.

The spontaneous decomposition of oxalacetate was then further investigated in order to throw some light on this second, non-enzymatic mechanism. It was found that both manganous ions $\left(\mathrm{Mn}^{++}\right)$and magnesium ions $\left(\mathrm{Mg}^{++}\right)$at concentrations of $10^{-2} \mathrm{M}$ considerably increase the autodecomposition of oxalacetate at $p \mathbf{H} 6 \cdot 5$, the former up to 75 per cent, the latter up to $\mathbf{4 0}$ per cent. At a final concentration of $10^{-3}$, however, these effects were much less pronounced. Ammonia, considerable amounts of which are undoubtedly released during boiling at strongly acid $p H$ values, did not affect the process in con. centrations of $10^{-3} M-10^{-2} M$, and therefore does not feature in the second process. These experiments also were carried out at $p \mathrm{H} 6 \cdot 5$. Finally, it was thought that iron, which may well be formed from hæmoglobin at low $p H$ values, might account for the increases observed. It was found that, for both ferrous and ferric ions at final concentrations of $10^{-2} \mathrm{M}$, increases of nearly 100 per cent over a period of one hour occurred. Ferric iron appeared to be the more active of the two, and dilution of both to $10^{-3} M$ did not reduce the effect nearly as greatly as was found with magnesium and manganous ions.

It thus appears that inorganic ferric iron may account for at least a part of the second, non-enzym. atic decomposition of oxalacetate observed at very low $p H$ values. However, other metals or factors, such as Breusch's heat-stable tissue extract ${ }^{4}$, cannot as yet be excluded.

Full details of this work will appear in the Australian Journal of Experimental Biology and Medical Science, and further work in connexion with both mechanisms is still in progress.

I wish to express my gratitude to Prof. J. G. Wood for a generous supply of the substrate, to Prof. M. L. Mitchell for continuous advice, and to M. Wellby for technical assistance.

${ }^{1}$ Nossal, P. M., Aust. J. Exp. Biol. Med. Sci., 26, Part 2 (in the press). 2 Evans, E. A., Vennesland, B., and Slotin, L., J. Biol. Chem., 147, 771 (1943).

${ }^{3}$ Krampitz, L. O., and Werkman, C. H., Biochem. J., 35, 595 (1941). - Breusch, F. L., Biochem. J., 33, 1757 (1939).

\section{AMERICAN PHILOSOPHICAL SOCIETY}

\section{ANNUAL REPORT}

$T$ HE yearbook for 1947 of the American Philo. sophical Society, Philadelphia, Pa., covering the year January 1-December 31,1947 , is a useful reference work, with its list of officers and committees, as well as of members, biographical memoirs (including those on Joseph Quincy Adams, Irving Fisher, M. Ganberg, P. Janet, H. S. Jennings and M. Planck) and reports of meetings. A brief history of the Society by E. G. Conklin, and the charter and laws are also included.

The report of the Committee on the Library records further accessions of more material relating to Benjamin Franklin and refers to progress during the year in the American Indian linguistic projects. At a conference called on October 18, 1947, to co-ordinate a programme in American archæology with that in linguistics, it was decided to restrict the area to be studied to the Iroquois and allied groups, and to compile a union list of Indian manuscript material as well as a manual for the use of amateur archæologists for the Iroquois area.

The report of the Committee of Publications gives some details of the foreign exchange list at December 31,1947 , revision of which has continued. In addition to the European libraries, a list is being drawn up of institutions in Latin America which should be placed on the regular exchange or on a temporary list for one year. Thirty-four papers were accepted for publication in the Proceedings during the year, as well as seven monographs for the Transactions and one book for the Memoirs ; two new volumes of the latter were issued in 1947. A list of publications during the year is appended to this report.

The report of the Committee on Research details the general principles adopted by the Committee in regard to grants and lists of the eighty-nine grants, totalling 80,103 dollars, made from the Penrose Fund during the year, with an analysis of the distribution by subjects and a summary of grants made from July 31,1933 , to December 31,1947 , totalling 846,605 dollars. A further nine grants, amounting to 8,300 dollars, were made from the E. R. Johnson Fund, and twenty-two grants, amounting to 46,610 
dollars, from the Reserve Fund for Post.War Expenditures Among the reports from recipients of grants included in this yearbook are those from $\mathrm{E}$. Hille on studies in the theory of semi-groups; W. A. Hiltner on photo-electric observations of selected WolfRayet stars, the polarization of the continuous radiation from early-type stars and selected eclipsing variable stars; and from F. B. Wood on photoelectrıc observations of eclipsing binaries. F. F. Cleveland reports on his studies on molecular spectra and molecular structure of olefins, acetylenic compounds, diastereoisomers, hexachloroethane, hexabromoethane and other compounds, C. P. Harnwell on the construction of a new type of beta-ray spectrograph to investigate the beta-ray spectra of radioelements emitting electrons and positrons, and $\mathrm{H}$. $\mathrm{H}$. Nielson on high-dispersion measurements on the infra-red spectra of the polyatomic molecules of hydrogen sulphide, acetylene, difluoromethane, dimethylacetylene, arsine and deuteroarsine. Work is described by $\mathbf{E}$. Berliner on the competitive bromination of alkylbenzenes for the purpose of ascertaining a possible conjugation of alkyl groups with the benzene ring, by J. L. and E. M. Irvin on the apparent acid dissociation constants, quinoline antimalarials such as 'Pamaquine' and other 4-amino- and 4-hydroxyquinolines, and by J. F. Mead on the action of lead tetra-acetate on amino-alcohols and amuno-glycols.

Studies in chemical embryology are reported by J. L. A. Brachet, on the quantitative spectrographic analysis of salt metabolism in developing Fundulus eggs and senescent Drosophila by O. C. Glaser, and on isolated embryonic amphibian cells with special reference to cellular structure, motility, aggregation and differentiation, and embryonic cell inclusions, particularly of yolk, lipochondria and microsomes by J. F. K. Holtfreter. A serological investigation of spaciation and evolution, using the Libby photronreflectometer, has been made by P. A. Moody, and experimental studies on the development of structure and function in the central nervous system of Fundulus embryos by J. M. Oppenheimer indicate that metrazol has a selective action on the cell-layers nearest the central canal. C. W. Clancy's investigation of the development of eye colour in Drosophila melanogaster anggests that the wild type allele of the vermilion gene is not only concerned with the reactions leading to the formation of the brown pigment component but also in some unknown way with the formation of the red pigment. J. F. Crow reports on the different susceptibility to ether of several closely related Drosophila species, H. Geiringer on the theoretical genetics of multivalent organisms, H. P. Hansen on post-glacial forest migrations and climate in Western Canada, and Ching Tsao Wei on the seed-borne diseases of soya beans. C. R. Procter has made an ecological study of a group of ferms, Dryopteris cristata and its relatives, in the eastern United States, and E. Girden a phylogenetic comparison of experimental drug dissociation. The electrical responses of the human retina to stimulation by light of various wave-lengths has been studied by L. A. Riggs, the application of the concepts of servotheory to biological systems by C. L. Kreezer; and the specificity and sensitivity of a further fifty colorimetric tests for eighteen amino-acids by A. P. Kline.

In the field of social sciences, studies of wholesale commodity prices in Philadelphia during the Revolutionary War and of industrial relations in Norway are reported; and, in that of the humanities, of the prehistoric archæology of the Tangier area of Morocco, preliminary excavations at Cottonwood Cave and Pueblo, Colorado, the distribution of petroglyphs in the United States and the archæology of Marajo Island, Brazil.

\section{WEST AFRICAN SEA-FISHERIES}

$M^{\mathrm{s}}$ R. G. A. STEVEN'S report of his work*, as the sole fisheries development officer, under acute difficulties of war-time conditions, in Sierra Leone, a Colony where the sea-fisheries were almost entirely undeveloped, has now been published. It should prove a most valuable guide to Mr. Steven's successors, and leaves one profoundly hoping that they will find their path made smoother for them.

There is little doubt that the sea-fisheries in these undeveloped regions could be made to yieId a vastly greater contribution to the sadly inadequate proportion of protein in the local diet. The small-scale trawling experiments with the Maid Honor (Skipper R. E. Brown) showed a yield of $86 \mathrm{lb}$. per hour from a 64-ft. headline trawl, which is sufficiently encouraging. In pre-war years a large British trawler with (say) 110-ft. headline gear, and vastly more expensive to run, could pay her way on double that yield. Since the report was written, we have been verbally informed that Maid Honor, still working in the same locality, is paying her way handsomely.

Fish are there in trawlable quantity, building of vessels up to the size of small motor-trawlers seems to be possible in the Colony and-probably Mr. Steven's most valuable achievement-a local team of net-makers was speedily trained to make good trawls and trammels. Machinery, of course, must be imported, but the only weak spot in the local contribution towards an incipient industry would seem to be need for further training of African seagoing trawlermen in repairing nets at sea.

One big question concerning the ground-fish remains unanswered : in the absence of fundamental knowledge of the ecology of those seas, we have no idea how much fishing the stocks can stand. Hence should any considerable industry develop, it must be controlled by guess-work, until some marine biological survey is completed. Mr. Steven justly points out that such surveys are beyond the resources of the smaller individual Colonies, for a central laboratory of some size and an ocean-going research vessel would be essential. Probably the subsequent working-up of the material would be best carried out in Great Britain, for a long experience of marine biological work overseas has left the present writer painfully aware of the almost complete absence of library facilities outside Europe (and the United States), apart from a very few of the larger cities in the greater British dominions.

Until these essential long-term researches are well advanced (which must take years of patient en. deavour), there is no practical alternative to $\mathrm{Mr}$. Steven's view that development officers must just go ahead developing as well as they can, and controlling as seems locally expedient; but the danger of bad or inadequate controls, when the cart is thus put before the horse, is very considerable. Mr. Steven admits this; but having worked in an area that seems

* Report on the Sea Fisheries of Sierra Leone. By G. A. Steven. (Freetown, 1945; London: Crown Agents for the Colonies, 1947.) 